Abstracta Iranica Iranica

Revue bibliographique pour le domaine irano-aryen

Volume 25 | 2004

Comptes rendus des publications de 2002

\title{
« Recent Speculations on the 'Traditional Date of Zoroaster' ». St. Ir. 31, 1, (2002), pp. 7-45.
}

\section{Rémy Boucharlat}

\section{(2) OpenEdition}

1 Journals

\section{Édition électronique}

URL : http://journals.openedition.org/abstractairanica/4792

DOI : 10.4000/abstractairanica.4792

ISSN : 1961-960X

Éditeur :

CNRS (UMR 7528 Mondes iraniens et indiens), Éditions de l'IFRI

\section{Édition imprimée}

Date de publication : 15 mai 2004

ISSN : 0240-8910

Référence électronique

Rémy Boucharlat, " « Recent Speculations on the 'Traditional Date of Zoroaster' ». St. Ir. 31, 1, (2002), pp. 7-45. », Abstracta Iranica [En ligne], Volume 25 | 2004, document 220, mis en ligne le 15 mars 2006, consulté le 25 septembre 2020. URL : http://journals.openedition.org/abstractairanica/4792 ; DOI : https://doi.org/10.4000/abstractairanica.4792

Ce document a été généré automatiquement le 25 septembre 2020.

Tous droits réservés 


\title{
« Recent Speculations on the 'Traditional Date of Zoroaster' " . St. Ir. 31, 1, (2002), pp. 7-45.
}

\author{
Rémy Boucharlat
}

1 Copieux « review article » de Gh. Gnoli, Zoroaster in History, 2000. Après avoir favorisé, avec des arguments forts, une date haute pour le prophète, avant $1000 \mathrm{BC}$, Gnoli est revenu à la date traditionnelle de 258 ans avant Alexandre, avec des arguments développés en quatre conférences. A. Sh. Sh. qui, à la différence de J. Kellens (c.r. $n^{\circ}$ 218), croit à l'historicité de Zoroastre, entreprend de démonter les raisonnements de Gnoli, et ceux de bien d'autres grands noms depuis Anquetil Duperron à la fin du $18^{\mathrm{e}} \mathrm{s}$. Pour lui, l'argumentation ne repose jamais sur des faits historiques mais sur des combinaisons de faits et d'interprétations. Accumulation n'est pas preuve, d'autant plus que les additions, quels que soient les computs correspondent rarement à 258. Les sources proprement iraniennes ne sont d'aucune aide, car elles ne s'intéressent pas à la chronologie mais au mieux aux années de règne. L'A. soutient son point de vue d'une date bien différente, qu'il n'indique pas ici, mais renvoie à son article paru dans BSOAS 60,1, (1977), dans lequel il proposait une date un peu antérieure à 1000 av. J.-C. Sa position actuelle se veut fondée sur la fiabilité des seules sources historiques babyloniennes; il développera son argumentation dans un prochain article que l'on attend impatiemment.

\section{INDEX}

Thèmes : 6.1. Zoroastrisme 
AUTEURS

RÉMY BOUCHARLAT

CNRS - Lyon 